\title{
Perceived usefulness, service quality and loyalty incentives: Effects on electronic service continuance
}

\author{
R. Naidoo \\ Department of Informatics, University of Pretoria, \\ Pretoria 0002, Republic of South Africa \\ A. Leonard* \\ Department of Informatics, University of Pretoria, \\ Pretoria 0002, Republic of South Africa \\ Awie.Leonard@up.ac.za
}

Received March 2002

\begin{abstract}
This paper examines the interrelationships between perceived usefulness, service quality and loyalty incentives on e-service continuance. The Technology Acceptance Model (TAM) was adapted from the information systems (IS) literature and integrated with theoretical and empirical findings from prior marketing research to theorise a model of e-service continuance. Results from a survey of a financial healthcare's e-service users indicate a positive relationship between perceived usefulness, service quality and loyalty incentives on continuance. Further analysis strongly suggest that continuance is determined solely by the higher perceived usefulness of the e-service while service quality is more effective at lower levels of perceived usefulness. Loyalty incentives did not moderate the relationship between perceived usefulness and continuance. Implications of these findings for firms contemplating e-service initiatives are discussed.
\end{abstract}

*To whom all correspondence should be addressed.

\section{Introduction}

This paper aims to develop a more holistic customer retention model for e-services (electronic services) with specific emphasis on continuance. E-service is viewed here as an automated customer service using information and communication technology independent of direct employee involvement. These self-service technologies allow users to service themselves more effectively and efficiently while providing productivity and cost saving benefits for the firm (Bitner, Brown \& Meuter, 2000; Dabholkar, 1996).

Continuance is described by Bhattacherjee (2001a: 352) as:

'The existence of a post-acceptance stage when use transcends conscious behaviour and becomes part of normal routine activity.'

In this definition continuance signifies post use evaluation. It assumes that users with favourable prior experiences are more likely to continue using an e-service. It also implies that post-use beliefs may not be the same as the set of prior beliefs that led to the initial adoption. Two well-known theories, namely innovation diffusion theory and relationship marketing theory, reinforce the importance of continuance. Firstly Rogers's (1983) theory of innovation diffusion argues that the long-term viability of most innovations will depend on their continued use. This is especially important because users are constantly re-evaluating their acceptance decisions to continue or discontinue using an innovation (Delone \& McLean, 1992). The second theoretical support for continuance comes from relationship marketing theories which also emphasises the need to retain existing customers (Rebstein, 2002; Gronroos, 1996; Gronroos, 1997; Palmer, 1996). According to relationship marketing theories, failure to keep promises may lead to discontinuance (Reardon \& McCorckle, 2002; Prendergast \& Marr, 1994; Ravald \& Gronroos, 1996). From an empirical standpoint, recent studies show many e-services experiencing difficulties at retaining their customers (Ahmad, 2002; Baveja, Rastogi \& Zook, 2002; Mahajan, Srinivasan \& Wind, 2002, Reichheld \& Schefter, 2000) Therefore these theories and empirical studies provide significant support for the continuance concept as a key consequent variable.

This study proposes to use key concepts from Marketing and Information Systems to develop a model explaining continuance. Perceived usefulness, service quality and loyalty incentives are hypothesised to influence the customer's decision to continue using an e-service. The paper starts with a brief description of the limitations of the research study. The following section uses TAM as the 
theoretical framework to expand on the three key factors influencing continuance and to state the study's hypotheses (Venkatesh \& Davis, 2000; Davis, 1989). The third section describes the methodology used to empirically test the research model. The fourth section presents the results and discusses the study's key findings. The final section concludes with some suggestions for practitioners and future research efforts.

\section{Research limitations}

The present research has several limitations that should be noted. Firstly, the study was based on a health insurance product. Since this is a fairly high touch service with higher risks, customers may want a long-term relationship as compared to low involvement products. This attitude may influence the decision to remain loyal to the web channel despite perceived lower levels of service provided by the online channel. Therefore these findings must be confirmed for other e-service firms.

Secondly, the study also suffered from biases inherent in most voluntary survey-based research. Either very satisfied or very dissatisfied users are generally more likely to respond to a customer survey. In the case of this survey the responses were skewed towards respondents who were willing to continue using the e-service. In addition the research focused on post-adoption behaviour. This means that potential new customers were not researched. Similarly, those users who had discontinued using the e-service were not researched. Segmentation analysis may provide invaluable insight on continuance behaviour. For instance, the effectiveness of loyalty incentives on retention may vary for different market segments.

Thirdly, the study examined a limited set of variables suggested by the service marketing and information systems literature. There can conceivably be other potential predictors of continuance. Ease of use was not incorporated into the model, but may be useful in explaining continuance where there are competing channels. Finally, although the constructs of service quality, perceived usefulness and loyalty incentives are conceptualised separately, they appear to be related to some higher order concept. Moreover, despite steps being taken to reduce multicollinearity, some effects may still be present. As a result the interaction terms must be interpreted with caution, as both moderators were correlated to both continuance and perceived usefulness.

\section{Hypotheses}

\section{Perceived usefulness}

Usefulness, the most salient belief in TAM, shows that a user's perception about the potential benefits of using a technology engenders positive effect towards it (Davis, Bargozzi \& Warshaw, 1989; Davis, 1989, Davis, Bargozzi \& Warshaw, 1992). Empirical support for the relationship between usefulness and attitude has been provided by a number of studies (Adams, Nelson \& Todd, 1992; Mathieson, 1991). Although these studies have been limited to job-related contexts where few information system alternatives are available, perceived usefulness attributes, such as convenience, intuitively apply to the competitive eservice context. This view has been supported by the marketing literature findings that convenience, saving time and money, being in control and avoiding interpersonal interaction are some of the benefits that customers seek in self-service technology (Reardon \& McCorckle, 2002; Meuter, Ostrom, Roundtree \& Bitner, 2000; Dabholkar, 1996; Bolton \& Drew, 1991; Zeithaml, 1988). This relationship has also been recently observed in the context of e-service use (Gefen, Karahana \& Straub, 2003; Chen, Gillenson \& Sherrell, 2002; Bhattacherjee, 2001a; Bhattacherjee, 2001b; Karahana, Straub \& Chervany, 1999; Kenney, 1999). Some studies found strong support for perceived usefulness during post-acceptance stages (Gefen et al., 2003; Karahana, et al., 1999) other studies offered only mild support (Bhattacherjee, 2001a; Bhattacherjee, 2001b). This paper asserts that there is a positive association between the user beliefs about the usefulness of an e-service and their continuance intentions. Hence the paper's first hypothesis states that:

H1: There is a positive association between users' beliefs about the usefulness of an e-service and their continuance intention.

\section{Service quality}

Previous service quality research in traditional and IS organisations demonstrate strong empirical support for a positive relationship between service quality and future patronage intentions (Ruyter, Bloemer \& Peeters, 1997; Dabholkar, 1996; Pitt, Watson \& Kavan, 1995; Taylor \& Baker, 1994; Kettinger \& Lee, 1994; Zeithaml, Berry \& Parasuraman, 1996). Therefore this research proposes that the service quality-continuance relationship will also hold for e-services. Only three dimensions of service quality, namely trust, reliability and responsiveness, are included in this model. Customers seem to use these three dimensions irrespective of service type they are evaluating (Singh \& Sirdeshmukh, 2000; Zeithaml, Berry \& Parasuraman, 1988; Zeithaml, Parasuraman \& Malthotra, 2002). It was found that other dimensions such as tangibles and empathy do not capture service quality significantly in an online channel, and as such these were excluded from this study (Voss, 2003; Devraj, Fan \& Kohli, 2002; Chaffey \& Edgar, 2000). Based on these three dimensions, this paper expects that overall perceived service quality will have a positive effect on user continuance. Therefore this research proposes a second hypothesis:

H2: There is an overall positive association between users' beliefs about the service quality of an e-service and their continuance intention. 


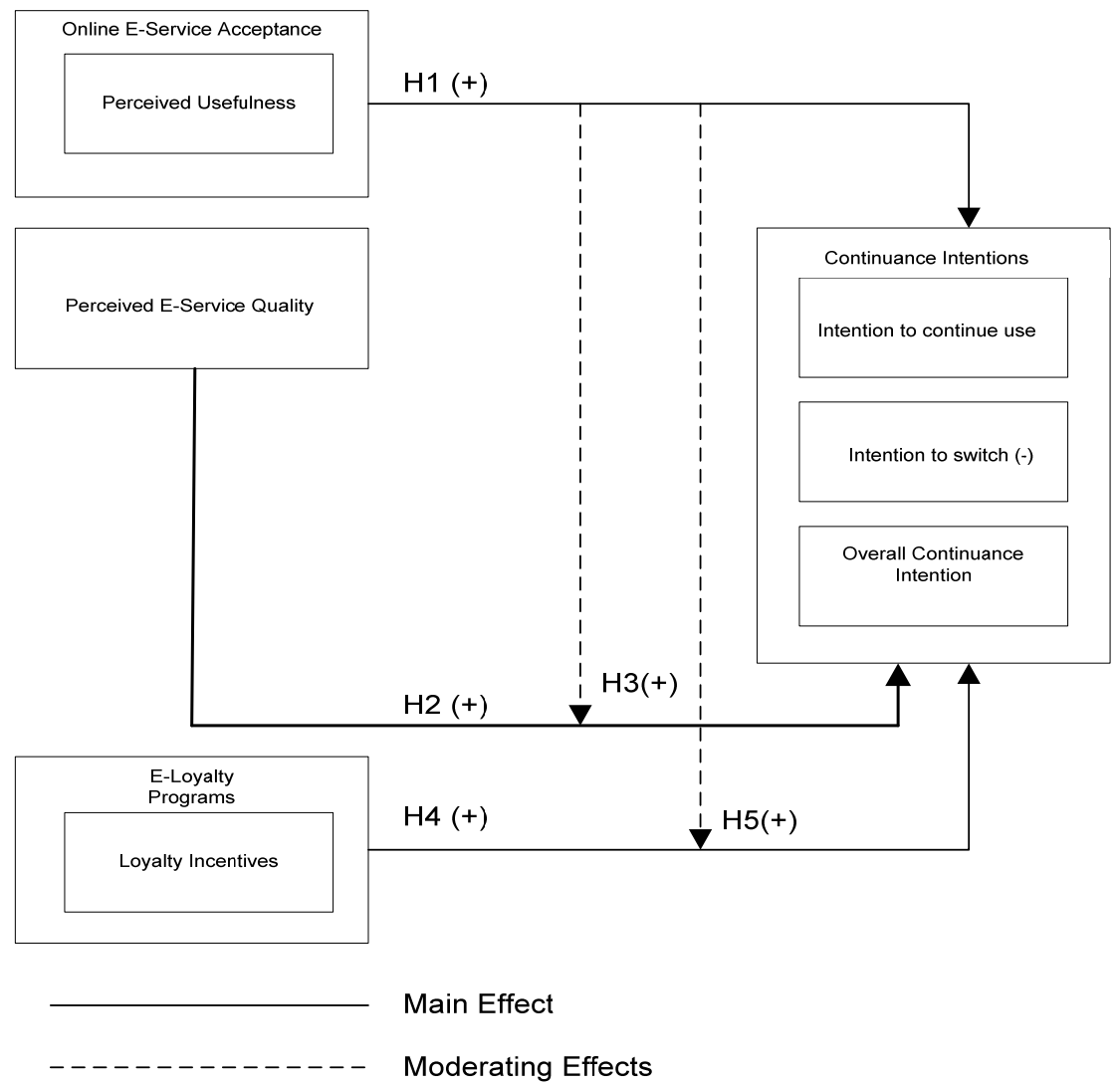

Figure 1: e-Service Continuance Model

Note: Adapted from the Technology Acceptance Model (Davis, 1989).

\section{Service quality and perceived usefulness}

It is reasonable to assert that the interactions between perceived usefulness and service quality may explain more variance in user continuance intention than do the simple main effects. Users may continue to use a useful e-service even though they are dissatisfied with the service quality (Christopher, 1996). This research proposes a moderation effect of perceived usefulness on the link between service quality and continuance. Therefore the third hypothesis suggests that by conceptualising service quality and perceived usefulness as acting jointly to impact continuance behaviour increases our ability to explain more of the variance in customer continuance intentions than relationships considered so far.

H3: Perceived usefulness will moderate the relationship between service quality beliefs and continuance intention.

\section{Loyalty incentives}

Many e-services are actively instituting loyalty programs and incentives to retain customers. However there is very little prior empirical research examining the effect of loyalty programmes on future customer patronage. Preliminary examinations by some researchers have not reported any significant effect of incentives on loyalty (Bhattacherjee, 2001a; Dowlings \& Uncles, 1997; Reinartz \& Kumar, 2002). Despite the scant attention devoted to studying the influence of loyalty incentives on continuance, the literature argues that a well executed program provides both a psychological and economic reluctance for customers to defect (O'Malley, 1998; Duffy, 1998). Two theories support this notion. Firstly, according to agency theory, incentive benefits can align the consumer's behaviour to support the firm's goals, in this case continue using the firm's e-services (Bhattacherjee, 2001a; Singh \& Sirdeshmukh, 2000). Secondly, cognitive-learning theory suggests that benefits representing value to the customer can also encourage loyal attitudes and behaviour (O’Brian \& Jones, 1995). This paper supports the notion that loyalty incentives can be effective in influencing continuance behaviour and consequently the fourth hypothesis states that:

H4: There is a positive association between users' beliefs about the loyalty incentives of an $e$ service and their continuance intentions. 
There has been virtually no prior research that compared retention strategies such as value enhancement with loyalty incentives. Some researchers found that loyalty program members perceive greater losses on quality, price and benefit aspects than non-members (Bolton, Kannan \& Bramlett, 2000). Others such as Bhattacherjee (2001a) found that the interaction between perceived usefulness and loyalty incentive performed significantly better at explaining user continuance intention variance. These findings suggest that loyalty incentives are most effective when the e-service is perceived to be useful as well. Therefore it is proposed that perceived usefulness and loyalty incentives act jointly to impact the continuance intention. It follows that:

H5. Loyalty incentives will moderate the relationship between perceived usefulness beliefs and continuance intention.

\section{Research methodology}

\section{Sample and data collection}

An online questionnaire was posted on a financial healthcare firm's website. At the time the website had more than 220 000 active registered users and an estimated 11000 unique daily visitors. Users were prompted to participate via a short message placed on the poll and other feedback sections of the website. 186 responses were collected over a period of two weeks in the middle of September 2003. 8 incomplete responses were disregarded. The final sample consisted of 178 usable responses. The sample characteristics are presented in Table (i) below.

\section{Measurement of the study's variables}

Four constructs were measured in this study: user continuance intention, perceived service quality, perceived usefulness and loyalty incentives. To maintain overall consistency they were measured using seven-point, Likert scales, ranging from 'strongly disagree' to 'strongly agree'. Continuance intention was measured using three items from Bhattacherjee's (2001a) continuance scale. Perceived usefulness was measured by items used by Davis et al (1989). Trust, Reliability and Responsiveness represented service quality. During this research WEBQUAL, .comQ and SERVQUAL were the only psychometrically sound instruments that were available for assessing e-service quality (Loiacono, Watson \& Goohue, 2002; Parasuraman et al., 1991; Wolfinbarger \& Gilly, 2002). Bhattacherjee's (2001a) three-item scale was used to measure loyalty incentives. Appendix A lists the study's constructs and measures. The instrument was pre-tested for face validity by 4 academics and 2 senior e-commerce executives. Furthermore prior to administrating the survey a convenience sample of 12 users completed the survey in a test environment. The survey questions with the instruction letter appear in Appendix B.
Table 1: Characteristics of respondents

\begin{tabular}{crc}
\hline & Number & Percentage (\%) \\
\hline 1. Gender & & \\
Male & 95 & 53,37 \\
Female & 83 & 46,63 \\
Total & 178 & 100,00 \\
& & \\
20-25 & & \\
$26-30$ & 39 & 20,91 \\
$31-35$ & 57 & 33,02 \\
$36-40$ & 42 & 23,60 \\
$40-45$ & 12 & 6,74 \\
Greater than 45 & 15 & 8,43 \\
Total & 13 & 7,30 \\
Group & 178 & 100,00 \\
3. Experience with particular Web site* & \\
Less than 6 months & 46 & 25,84 \\
6-12 months & 41 & 23,03 \\
13-24 months & 67 & 37,64 \\
Greater than 24 months & 24 & 13,48 \\
Total & 178 & 100,00 \\
\hline & & \\
Note: Registration date was used to calculate the \\
user's experience with the Web site.
\end{tabular}

\section{Empirical results}

\section{Descriptive statistics}

Descriptive statistics and Cronbach alphas are depicted in Table (ii). Alpha values which range from .70 to .89 are acceptable for demonstrating reliability (Hair, Anderson, Tatham \& Black, 1998). The main constructs means and standard deviations are also presented. Scores for perceived usefulness (mean=6.07, $\mathrm{SD}=.99$ ) suggest that the Web site provides value to the majority of respondents. Continuance intentions had the highest performance score (mean=6.33, $\mathrm{SD}=1.00$ ). This score suggests that by and large users intend to continue using the e-service.

\section{Hypotheses 1, 2, 4}

Table (ii) shows the correlation analysis results. Hypotheses 1,2 and 4 are supported as there was a strong positive correlation between beliefs about perceived usefulness and continuance intention $(\mathrm{r}=.753, \mathrm{n}=178, \mathrm{p}<0.01)$ as was the composite perceived service quality construct's relationship with continuance intentions $(\mathrm{r}=.60, \mathrm{n}=178, \mathrm{p}<0.01)$. Loyalty incentives was moderately and positively associated to continuance intentions $(\mathrm{r}=.383, \mathrm{p}<0.01)$. As expected this study provides additional support for the argument that perceived usefulness leads to positive intentions to continue using computer technology. More importantly, this study shows that perceived usefulness is also relevant in the eservice context where the Web interface is in use. Unlike Bhattacherjee (2001a; 2001b) who found only weak support for usefulness on user continuance intentions of e-services, 
this study generally supports the findings of recent TAM based e-services studies (Gefen et al., 2003; Karahana et al., 1999). The loading of the service quality dimensions appear to be in line with the more recent work on WEBQUAL and led to positive intentions to continue using e-services (Loiacono et al., 2002; Zeithaml et al., 2002). Additional support has also been provided for the argument that loyalty incentives lead to positive intentions to continue using eservices.

The 3 independent variables were evaluated separately to determine their unique contribution to explaining continuance. Standard multiple regression (Table (iv)) revealed that only perceived usefulness makes a strong unique contribution (Sig. less than .05, beta=.65, after rounding) to predicting continuance.

\section{Hypothesis 3}

Hypothesis 3 stated that perceived usefulness will moderate the relationship between service quality perceptions and continuance intention. In testing hypothesis 3 , the procedure recommended by Aiken and West (1991) was followed. Regression analysis was undertaken hierarchically to test the interaction effect over and above the simple effects of the independent variables. The resultant models are shown in Table (v). The results showed an increase in R-square from $57.4 \%$ to $63.6 \%$ and is statistically significant at (beta= $.302, \mathrm{p}<0.01$ ) explaining an additional $6 \%$ of continuance intention variation. Furthermore, the interaction effect of perceived usefulness with service quality (model 2) was significant $[\mathrm{F}(3,174)=103.331, \mathrm{p}<.0005]$. The interaction was plotted and interpreted using the guidelines suggested by Aiken and West (1991) (See Figure 2).

Probing the interaction by plotting confirms a positive relationship between 'service quality' and 'continuance intentions'. However, the low perceived usefulness (-1SD) line has a steeper slope than the high perceived usefulness slope (+1SD). This suggests that continuance intention will increase when service quality increases but at a faster rate when perceived usefulness is low than high. To confirm these results the sample was split into 2 groups (high and low PU) using SPSS based on mean split correlations between service quality on continuance intentions in each of the 2 groups (See Table (vi)). Results of this procedure confirm the moderating effect of perceived usefulness on the service quality - continuance intention relationship.

\section{Hypothesis 5}

Hypothesis 5 suggested a significant interaction effect between loyalty incentives and perceived usefulness on continuance. No evidence was found to support this hypothesis. In this e-service context, loyalty incentive is ineffective even during low levels of perceived usefulness.
Table 2: Instrument reliabilities and validities

\begin{tabular}{lrrrrc}
\hline Construct & $\begin{array}{c}\text { Number } \\
\text { of Items }\end{array}$ & Mean & SD & $\begin{array}{c}\text { Cronbach } \\
\text { alpha }\end{array}$ & $\begin{array}{c}\text { Minimum } \\
\text { factor } \\
\text { loading }\end{array}$ \\
\hline $\begin{array}{l}\text { Continuance } \\
\text { intention }\end{array}$ & 3 & $6,3 \Xi$ & $1,0 C$ &, 701 &, 682 \\
$\begin{array}{l}\text { Usefulness } \\
\text { Service }\end{array}$ & 4 & 6,07 & $0,9 \subseteq$ &, 885 &, 809 \\
$\begin{array}{l}\text { Quality } \\
\text { Loyalty }\end{array}$ & 9 & 5,25 & 1,52 &, 703 &, 636 \\
Incentives & 3 & 5,24 & 1,44 &, 759 &, 739 \\
\hline
\end{tabular}

Note: All loadings were greater than 0,60. 7-point scale: $1=$ Strongly Disagree, $7=$ Strongly Agree

Table 3: Correlation matrix showing the relationship between continuance intentions and perceived usefulness, service quality and loyalty incentives

Construct Continuance Intentions

\begin{tabular}{ll}
\hline & \\
Perceived Usefulness &, $753^{*}$ \\
Service Quality &, $601^{*}$ \\
Loyalty Incentives &, $383^{*}$ \\
\hline
\end{tabular}

Note: (*) Correlation is significant at the 0,01 level

Table 4: Multiple regression of loyalty, perceived service quality and perceived usefulness on continuance intentions

\begin{tabular}{lccc}
\hline \multicolumn{1}{c}{ Y } & Beta & T value & Sig. \\
\hline & & & \\
Loyalty Incentives &, 044 & 9,336 &, 440 \\
Perceived Service Quality &, 128 & 1,761 &, 080 \\
Perceived Usefulness &, $645^{*}$ &, 744 &, 000 \\
Adj R2 = ,573 & & & \\
\hline
\end{tabular}

Note: Standardised beta coefficients are shown for the independent variables; $*=\mathrm{p}<0,05$ 


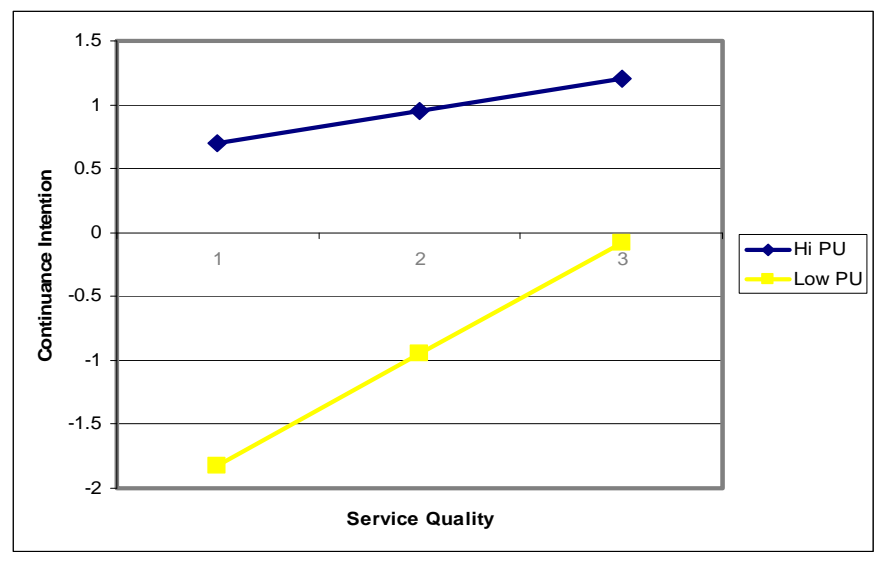

Figure 2: Plot of the service quality - perceived usefulness interaction

Table 5: Multiple regression analysis of perceived usefulness as a moderator

\begin{tabular}{|c|c|c|}
\hline Independent Variable & Model 1 & Model 2 \\
\hline \multirow{3}{*}{$\begin{array}{l}\text { Service Quality } \\
\text { Perceived Usefulness } \\
\text { Service Quality x Perceived } \\
\text { Usefulness }\end{array}$} & ,146 & ,104 \\
\hline & ,652* & ,518 \\
\hline & &,$- 302 *$ \\
\hline$R^{2}$ &, 578 & ,642 \\
\hline $\begin{array}{l}\text { Adjusted } R^{2} \\
F\end{array}$ & $\begin{array}{c}, 574 \\
120,059\end{array}$ & $\begin{array}{c}, 636 \\
104,109\end{array}$ \\
\hline
\end{tabular}

Notes: Standardised beta coefficients are shown for the independent variables; ${ }^{*}=\mathrm{p}<, 05$; Change in $R^{2}=6 \%$.

Table 6: Sub group matrix showing the relationship between continuance intentions and service quality with low and high levels of perceived usefulness

\begin{tabular}{lcc} 
Independent Variable & Continuance & Service Quality \\
& & \\
\hline Continuance (PU = low) & 1,00 &, $522^{*}$ \\
Service Quality &, 522 & 1,00 \\
Continuance (PU=high) & 1,00 &, $155^{*}$ \\
Service Quality &, 155 & 1,00 \\
\end{tabular}

* Significant at $\mathrm{p}<0,01$.
Table 7: Loyalty incentives as a moderator

\begin{tabular}{lcc}
\hline \multicolumn{1}{c}{ Independent Variable } & Model 1 & Model 2 \\
& & \\
& &, $688^{*}$ \\
Perceived Usefulness &, $721^{*}$ &, 070 \\
Loyalty Incentives &, 077 &,- 095 \\
$\begin{array}{l}\text { Perceived Usefulness x Loyalty } \\
\text { Incentives }\end{array}$ &, 572 &, 580 \\
$R^{2}$ &, 568 &, 573 \\
$\begin{array}{l}\text { Adjusted } R^{2} \\
F\end{array}$ & 117,127 & 80,168 \\
\hline $\begin{array}{l}\text { Notes: Standardised beta coefficients are shown for the independent } \\
\text { variables; } *=\mathrm{p}<, 05 .\end{array}$ & \\
\hline
\end{tabular}

\section{Conclusion}

With the advent of the Internet and the proliferation of eservices continuance, is emerging as a prominent stream of research in Information Systems. This is a critical issue in the context of competing websites and alternative channels. A survey of 178 e-service users demonstrates that perceived usefulness is a dominant predictor of continuance in the eservice context.

The finding that service quality evaluation has a strong positive influence on e-service continuance, justifies the recent attention given to service quality issues in the literature. The research results also provide strategic direction by providing evidence that perceived usefulness has the strongest affect on the dependant variable. This suggests that management should focus on the delivery of value adding functionality. When combined with perceived usefulness, the independent effect of service quality and loyalty incentives on continuance is small. On the basis of these findings, tactics that focus on service quality may only have a minimal effect on continuance. However, there are indications that service quality and loyalty do play important roles in determining the perceived usefulness of the Web site. Trust and reliability correlated highly with perceived usefulness, suggesting that users place more emphasis on the e-service provider's reputation in the e-health context. By including the role of perceived usefulness, decisions to improve customer retention should be more effective. Therefore both perceived usefulness, service quality and loyalty incentives must be incorporated into continuance models to provide a clearer picture of the drivers of continuance.

\section{Implications for management}

There are several practical implications that can be derived from the findings. Firstly, the findings emphasise perceived usefulness over service quality and loyalty incentives. This implies that a priority for practitioners in the context of competing websites and alternative channels is focusing their 
development efforts on end user requirements. Firms should assess to what extent their websites are useful, relative to competing websites and channels. Furthermore, firms should focus on cues that users use that signal usefulness in early stages of the development process. Therefore it makes sense that practitioners focus their attention in this area to get the biggest return on investment. It is the firm's responsibility to educate users and raise awareness on what types of benefits they offer the user and, secondly, how the user can take advantage of these benefits.

Another implication for management from the findings concerns the important effect of service quality on perceived usefulness. When combined with perceived usefulness, service quality does not appear to be a strong predictor of continuance. Although service quality does not appear to have a strong independent effect on continuance, it does have a strong relationship with perceived usefulness. This may be site specific, since the web site in this study provides information as its core service. As such trust and reliability, although important, are not strong influencers of user continuance.

Lack of trust and reliability online, may lead to lack of trust of the offline firm. To focus on maintaining the trust, firms need to understand those elements that communicate trust to the user. These relate both to the components communicating the content of the web site and transactional processes. Since trust is based on the user's experience, the more trustworthy the relationship with the e-service firm, the easier it is for the e-service firm to create a habitual relationship. In contrast, site responsiveness showed a less substantial positive correlation with continuance. Despite this, all the service quality dimensions could be particularly important for novice users who have not made up their mind if the site is useful.

This research shows that if the e-service offers value, it may not need to resort to any form of incentive to stimulate continued usage. To progress, future continuance research could examine loyalty incentives in both pre-acceptance and post-acceptance stages of e-service use. Given the widespread use of incentives, such an assessment could shed more light on the role of incentives in attracting and retaining users. Finally, another study could look at developing a more comprehensive perceived usefulness scale. The current perceived usefulness scale has been developed for the work-related context. The scale can be made more suitable for e-service firms by incorporating price and other e-service value factors.

\section{References}

Adams, D.A., Nelson, R.R. \& Todd, P.A. 1992. 'Perceived usefulness, ease of use, and usage of information technology: A replication', MIS Quarterly, June: 227-247.
Ahmad, S. 2002. 'Service failures and customer defection: A closer look at online shopping experiences', Managing Service Quality, 23(3): 19-29.

Aiken, L.S. \& West, S.G. 1991. Multiple regression: Testing and interpreting interactions. New York: Sage Publications.

Baveja, S.S., Rastogi, S. \& Zook, C. 2000. The value of online customer loyalty. Atlanta: Mainspring, Bain \& Company.

Bhattacherjee, A. 2001a. 'An empirical analysis of the antecedents of electronic commerce service continuance', Decision Support Systems, 32: 201-214.

Bhattacherjee, A. 2001b. 'Understanding information systems continuance: An expectation-confirmation model', MIS Quarterly, 25(3): 351-370.

Bitner, M.J., Brown, S.W. \& Meuter, M.L. 2000. 'Technology infusion in service encounters', Journal of the Academy of Marketing Science, 28(1): 138-149.

Bolton, R.N. \& Drew, J.H. 1991. 'A multistage model of customers' assessments of service quality and value', Journal of Consumer Research, 17: 375-385.

Bolton, R.N., Kannan, P.K. \& Bramlett, M.D. 2000. 'Implications of loyalty program membership and service experiences for customer retention and value', Journal of the Academy of Marketing Science, 28: 95-108.

Chaffey, D. \& Edgar, M. 2000. 'Measuring online service quality', Journal of Targeting, Analysis and Measurement for Marketing, 8(4): 363-378.

Chen, L., Gillenson, M.L. \& Sherrell, D.L. 2002. 'Enticing online customers: An extended technology acceptance perspective', Information \& Management, 13(3): 316-333.

Christopher, M. 1996. 'From brand values to customer value', Journal of Marketing Practice: Applied Marketing Science, 2(1): 55-66.

Dabholkar, P.A. 1996. 'Consumer evaluation of new technology based self-service options: An investigation of alternative models of service quality', International Journal of Research in Marketing, 13(1): 29-51.

Dabholkar, P.A. \& Bagozzi, R.P. 2002. 'An attitudinal model of technology-based self-service: Moderating effects of consumer traits and situational factors', Journal of the Academy of Marketing Science, 30(3): 184-201.

Davis, F.D. 1989. 'Perceived usefulness, perceived ease of use, and user acceptance of information technology', MIS Quarterly, September: 319 - 339. 
Davis, F.D, Bagozzi, R.P. \& Warshaw, P, R. 1989. 'User acceptance of computer technology: A comparison of two theoretical models', Management Science, 35(8): 982-1003.

Davis, F.D., Bagozzi, R.P. \& Warshaw, P.R. 1992. 'Extrinsic and intrinsic motivation to use computers in the workplace', Journal of Applied Social Psychology, 22(4): 1111-1132.

Delone, W.H. \& McLean, E.R. 1992. 'Information systems success: The quest for the dependant variable', Information Systems Research, 3(1): 60-95.

Devraj, S., Fan, M. \& Kohli, R. 2002. 'Antecedents of B2C channel and preference: Validating e-commerce metrics', Information Systems Research, 13(3): 316-333.

Dowling, G.R. \& Uncles, M. 1997. 'Do customer loyalty programs really work', Sloan Management Review, Summer: 71-82.

Duffy, D.L. 1998. 'Customer loyalty strategies', Journal of Consumer Marketing, 15(5): 435-448.

Ganesh, J., Arnold, M.J. \& Reynolds, K.E. 2000. 'Understanding the customer base of service providers: An examination of the differences between switchers and stayers', Journal of Marketing, 64: 65-87.

Gefen, D., Karahana, E. \& Straub, D. 2003. 'Trust and TAM in online shopping: An integrated model', MIS Quarterly, 27(1): 51-90.

Gronroos, C. 1996. 'Relationship marketing: Strategic and tactical implications’, Management Decision, 34(3): 5-14.

Gronroos, C. 1997. 'From marketing mix to relationship marketing - towards a paradigm shift in marketing', Management Decision, 35(4): 322 - 339.

Hair, J.F., Anderson, R.E., Tatham, R.L. \& Black, W.C. 1998. Multivariate data analysis. New Jersey: Prentice-Hall International Inc.

Karahana, E., Straub, D.W. \& Chervany, N.L. 1999. 'Information technology adoption across time: A crosssectional comparison of pre-adoption and post-adoption beliefs', MIS Quarterly, 23(2): 183-213.

Kenney, R.L. 1999. 'The value of Internet commerce to the customer’, Management Science, 45(4): 533-542.

Kettinger, W.J. \& Lee, C.C. 1994. 'Perceived service quality and user satisfaction with the information services functions', Decision Sciences, 25(5/6): 737-766.

Loiacono, E.T., Watson, R.T. \& Goodhue, D.L. 2002. 'WEBQUAL: A measure of service quality', Marketing
Theory and Applications: American Marketing Association, 13: $43-438$.

Mahajan, V., Srinivasan, R. \& Wind, J. 2002. 'The Dot.com retail failures of 2000: Were there any winners?', Journal of the Academy of Marketing Science, 30(4): 474486.

Mathieson, K. 1991. 'Predicting user intentions: Comparing the technology acceptance model with the theory of planned behaviour', Information Systems Research, 2(3): 173-191.

Meuter, M.L., Ostrom, A.L., Roundtree, R.I. \& Bitner, M.J. 2000. 'Self-service technologies: Understanding customer satisfaction with technology-based encounters', Journal of Marketing. 64: 50 - 64.

O'Brien, L. \& Jones, C. 1995. 'Do rewards really create loyalty?’, Harvard Business Review, May-June: 75-82.

O'Malley, L. 1998. 'Can loyalty schemes really build loyalty?', Marketing Intelligence and Planning, 16(1): 4755.

Palmer, A.J. 1996. 'Relationship marketing: a universal paradigm or management fad', The Learning Organisation, 3(3): 18-25.

Parasuraman, A., Zeithaml, V.A. \& Berry, L.L. 1991. 'Refinement and reassessment of the SERVQUAL scale', Journal of Retailing, 67(4): 420 - 450.

Pitt, L.F., Watson, R.T., \& Kavan, C.B. 1995. 'Service quality: A measure of information systems effectiveness', MIS Quarterly, June: 173 - 1879.

Prendergast, G.P. \& Marr, N.E. 1994. 'Disenchantment discontinuance in the diffusion of self-service technologies in the services industry: A case study in retail banking', Journal of International Consumer Marketing, 7(2): 25-40.

Ravald, A. \& Gronroos, C. 1996. 'The value concept and relationship marketing', European Journal of Marketing, 30(2): 19-30.

Reardon, J. \& McCorckle, D.E. 2002. 'A consumer model for channel switching behaviour', International Journal of Retail and Distribution Management, 30(4): 179-185.

Reibstein, D.J. 2002. 'What attracts customers to online stores, and what keeps them coming back?', Journal of the Academy of Marketing Science, 30(4): 465-473.

Reichheld, F.F. \& Schefter, P. 2000. 'E-loyalty: Your secret weapon on the Web', Harvard Business Review, JulyAugust: 105-113.

Reinartz, W. \& Kumar, V. 2002. 'The mismanagement of customer loyalty’, Harvard Business Review. July: 86-94. 
Rogers, E.M. 1983. Diffusion of innovations. New York: Free Press.

Ruyter, K., Bloemer, J. \& Peeters, P. 1997. 'Merging service quality and service satisfaction: An empirical test of an integrative model', Journal of Economic Psychology, 18: 387 - 406.

Shapiro, C. \& Varian, H.R. 1998. Information rules: A strategic guide to the network economy. Boston: Harvard Business School Press.

Singh, J. \& Sirdeshmukh, D. 2000. 'Agency and trust mechanisms in consumer satisfaction and loyalty ludgements', Journal of the Academy of Marketing Science, 28(1): 150-167.

Taylor, S.A. \& Baker, T.L. 1994. 'An assessment of the relationship between service quality and customer satisfaction in the formation of consumers' purchase intentions', Journal of Retailing, 70(2): 163-178.

Venkatesh, V. \& Davis, S.G. 2000. 'A theoretical extension of the technology acceptance model: Four longitudinal field studies', Management Science, 46(2): 186-204.

Voss, C.A. 2003. 'Rethinking paradigms of service - service in a virtual environment', International Journal of Operations \& Production Management, 23(1): 88-104.

Wolfinbarger, M. \& Gilly, M.C. 2002. 'comQ: Dimensionalising, measuring and predicting quality of the etail experience'. Working Paper No. 02-100, Massachusetts Marketing Science Institute.

Zeithaml, V.A. 1988. 'Consumer perceptions of price, quality and value: A means-ends model of and synthesis of evidence', Journal of Marketing, 52: 2-22.

Zeithaml, V.A., Berry, L.L. \& Parasuraman, A. 1988. 'Communication and control processes in the delivery of service quality’, Journal of Marketing, 52: 35-48.

Zeithaml, V.A., Berry, L.L. \& Parasuraman, A. 1996. 'The behavioural consequences of service quality', Journal of Marketing, 60: 31-46.

Zeithaml, V.A., Parasuraman, A. \& Berry, L.L. 1990. Delivering quality service: Balancing customer perceptions and expectations. New York: Free Press,

Zeithaml, V.A., Parasuraman, A. \& Malhotra, A. 2000. 'A conceptual framework for understanding e-service quality: Implications for future research and managerial practice'. Working Paper No. 00-115, Massachusetts Marketing Science Institute, 1-46.

Zeithaml, V.A., Parasuraman, A. \& Malhotra, A. 2002. 'Service quality delivery through web sites: A critical review of extant knowledge', Journal of the Academy of Marketing Science, 30(4): 362-375. 


\section{Appendix B. Questionnaire Instruction \& Items}

\section{Survey Instructions}

Thank you for participating in this survey. For each of the following statements, please indicate your perception of this Web site by clicking on the checkbox in the last column. Please show the extent you think the Web site possesses a feature described by each statement. If you strongly agree, click on 7. If you strongly disagree, click on 1. If your feeling is less strong, choose one of the numbers in the middle. There are no right or wrong answers - all we are interested in is a number that truly reflects your perception about this Web site.

Variable items and key dimensions.

Continuance Intentions:

CI1 I intend to continue using the Web site rather than discontinue its use

CI2 My intentions are to continue using the Web site rather than any alternative means

CI3 If I could, I would like to discontinue use of the Web site (-)

Perceived Usefulness:

PU1 Using the Web site gives me greater control in carrying out my tasks.

PU2 Using the Web site saves me time and effort over other means of performing the same task.

PU3 Using the Web site is a more effective way of servicing my needs

PU4 Overall I find the Web site very useful

Perceived Service Quality: Trust \& Reliability

T1 I feel safe about conducting transactions on the Web site

T2 I trust the Web site to keep my personal information safe

T3 I trust that the Web site administrators will not misuse my personal information

RL2 The Web site provides error free information

RL3 The Web site is usually reliable

Responsiveness

RL1 The Web site is always available when I need to use it

RS1 The Web site takes long to load(-)

RS2 The waiting time between my actions and Web site's response is acceptable.

RS3 The Web site loads quickly

\section{Loyalty Incentives:}

L1 The Web site offers me adequate incentives for its continued use

L2 I get rewarded appropriately for my continued patronage of the Web site

L3 The Web site does not give me enough incentives for my repeat visits (-) 